\title{
Fiscal Federalism and Good Governance in Nigeria Since Independence
}

\author{
Evalsam Samuel Ecoma, M.Sc. ${ }^{1}$, Chinyere Samuel Ecoma, Ph.D. ${ }^{2}$ \\ ${ }^{1}$ Department of Political Science and Public Administration, Igbinedion University, Okada, Okada - Nigeria. \\ ${ }^{2}$ Department of History and International Relations, Veritas University, Abuja, Abuja - Nigeria. \\ ecomaevalsam@gmail.com \\ ecomachinyere@yahoo.com
}

\begin{abstract}
Fiscal federalism deals with the division of resources and tax raising powers among federating units to enable them fulfill their constitutional obligations. This can only be true if there is no other financial subordination on the part of any of the levels of government. It means that neither the federal nor the State nor Local Government in a Federation should be dependent on each other in performing the statutory duties and functions devolved upon them in a federal constitution. Since it is fundamentally true that the challenges of fiscal federalism are enormous in Nigeria, the paper attempts to look into the importance of fiscal federalism for good governance in Nigeria. The paper noticed that the principle of fiscal autonomy and fiscal integrity are paramount aspects of the survival and continued existence of a truly federating system of government. The paper reveals that the contending issues and challenges of fiscal federalism could be in form of a mismatch between revenue sources and functions of the various tiers of government. The paper concludes by arguing that there is the prospect of a stable federation if anchored on arrangements rooted in equity, fairness and justice. The paper asserts further that the distribution of revenue should encourage each State and Local Government to improve internal revenue generation, as well as the devolution of fiscal power and responsibilities to component units.
\end{abstract}

Keywords: Fiscal Federalism, Good Governance, Fiscal Autonomy, Nigeria.

\section{INTRODUCTION}

There have been various views about federalism by different scholars. The concept of federalism is often inter-changed or synonymously used with concepts such as federal government and federations. For the purpose of this study, the term federalism which is the most widely used term will be adopted. Oyovbaire (1979) defines federalism as the interaction between conflict, consensus and resources which normally takes place in an arena- a value system which underpins the perception of this phenomenon by actors. Tamuno (2005) views federalism as that form of government where the component units of a political organisation participate in sharing power and functions in a co-operative manner. Okoli (2004) argued that federalism is a system of shared power between units of government. Hague and Harop (2001) opine that the distinctive feature of federalism is that legal sovereignty is shared between the federal government and the constituent states. They went further to add that a federal constitution creates layers of government with specific functions allocated to each. The relationship between federal and state governments according to Hague and Harrop is the crux of federalism. Friedrisech (1937) sees federalism as a union of group selves united by one or more common objectives but retaining their distinctive groups' beings for other purposes. Dicey (1924:2) defined federalism as a political invention which is intended to reconcile national unity and power with the maintenance of the right of the separate member states. Deutsche (1956) opines that federalism is putting every individual under many governments at one and the same time. So far as the individual is concerned, these governments coincide in domain, but differ in some respects, but not in others. One of these governments, the national or federal governs the entire country, while the other governs only a small part of the country. 
To Ricardo (1993), federalism is a process without required form or practice, a process constantly in a flux under evolution... a conceptualisation with some human systematic analysis, brought to show that federalism thrives in a continuous flux; that it involves fluidity wherein the federalists from the units allow for the process of continued evolution towards the emergence of the greater good for all through compromise in their diversities. It is imbued with capabilities inherent in the various units and subsuming them. Wheare (1965) views federalism as a system in which two levels of government- federal and regional [state] exist side by side with each possessing certain assigned functions. Writing along a similar line, Frederick (1968) defines federalism as a situation whereby the federal and regional governments are limited to their spheres and should be independent of the other. Nwabueze (1982) represents federalism essentially as an arrangement between governments, a constitutional device by which power is divided among the tiers of government within a country. Awa (1976) sees federalism as involving co-operation, bargaining and conflict. There has always been a measure of co-operation between the two levels of government, such co-operation increasing in scope and quality as the federation measures.

Riker (1975) views federalism as a political organisation in which the activities of government are divided between regional governments in such a way that each kind of government has some activities on which it makes final decisions. Thus, Grodzius quoted in Gamble and Payne (1996: 124) observed that federalism is a formal legal set of relationships aimed at the distribution of power between central and peripheral units of government. Livingston (1952) defines federalism as a political system that takes cognisance of the sociocultural environment, hence the processes and structures of the federal political system should be synchronised to suit the character of the socio-cultural environment. Salient issues such as historical political development, system of government, institutional structures of accommodation, inter alia must be considered in the workings and processes of federalism. Corroborating the above, Onwe (2011) maintained that federalism is the putting of understanding and bonds through agreement in laws between independent entities to satisfy the need for autonomy and freedom, on the one hand, and for order and security on the other hand. Finally, Elaigwu (1984) views federalism as an attempt to reflect the various diverse social, political and economic interests within the framework of a broader national unity.

\section{THE CoNCEPT OF Fiscal FEDERALISM}

Federalism represents a system of government that emphasises unity in diversity, division of powers between levels of government and limited autonomy to the constituent units. The units should exist as partners in progress and the relations among them cutting across the formal and legalistic division of powers (Mohammed, 2002:120). In Nigeria, the major concern in the division of functions and responsibilities to different levels of government in the federal political system appears to be the need to ensure adequate scope for the realisation of the political and economic aspirations of the people. This concern has to a large extent dictated specific public sector functions to be assigned to the level of government perceived to be most effective and efficient in performing them (Fajana, 2001: 106). The existence of division of powers or responsibilities within a federal system between the central and component units, necessitated the need for the sharing of fiscal powers. This makes for fiscal federalism. Mainly, fiscal federalism poses questions as to how the nature of financial relations in any federal system affects the distribution of the nation's wealth. Scholars have argued that in its working and processes, fiscal federalism is very much in accord with the American model of federalism. Jega (2007: 205) sees fiscal federalism as dealing with the issues of relationship between revenue generation and sharing in a federal system of government which has always been debatable and contentious. It revolves around the issues of equity and efficiency as rationale and justification for intergovernmental transfers.

Okigbo (1963:3) views fiscal federalism as the existence in one country of more than one level of government, each with different expenditure responsibilities and taxing powers. This connotes that consequent upon the division of sovereignty among different tiers of government, which forms the component units of the federation, is the allocation of functions and tax powers or jurisdiction among units. Mbanefoh (1990: 4) (Cited in Abubakar, 
2004: 21) notes that ideally, each level of government should be given adequate resources to enable it discharge its constitutional duties and responsibilities, but, as he immediately acknowledges, "in practice... it is virtually impossible in a federation to adjust the functions entrusted to the members to their financial resources..." Onimode (2000: 15) states that the principle of fiscal federalism deals with theoretical and institutional issues of intergovernmental fiscal relations and how these relations impinge on sound macroeconomic management. Nyong (1999) conceptualises fiscal federalism as the relations among the various levels of government in respect of the allocation of national revenue and tax powers within the federation. He asserts that the principle of fiscal federalism is anchored on revenue sharing (vertical) and distribution of revenue (horizontal) among various organs and tiers of government. Fiscal federalism in the Nigerian context involves the allocation of expenditure and taxation powers shared among the federal, state and local governments. Akindele et al (2002) opine that fiscal federalism was deeply rooted in the federal system of government. It involves the financial relationship among the three tiers of government. Ajibola (2008) defines fiscal federalism as intergovernmental fiscal relations defining functions and responsibilities among the various tiers of government as well as the financial resources to achieve stated objectives.

Fiscal federalism has been defined by Prof. K. C. Wheare in Ola Vincent (2001) as a method of dividing powers such that federal and state governments are each, within a sphere, co-ordinate and independent. David Hayman (1993) views fiscal federalism as "the division of taxing and expenditure functions among tiers of government". Ozor (2004: 342) argues that in a federalism, fiscal federalism entails the allocation of taxing power, federally collectable revenue and federal expenditure to the different component/levels of government in a federation so as to enable them discharge their constitutionally assigned functions and responsibilities to their citizens. To Nyong (1999), fiscal federalism is the relation among various levels of government in respect of the allocation of national revenue and tax powers within the federation. He asserts that the principle of fiscal federalism is anchored on revenue sharing (vertical) and distribution of revenue (horizontal) among various tiers of government. To Uche (2004), fiscal federalism is the criterion for government to share revenue among various tiers of government. This is one of the relevant inclusions in Section 162(2) of the Constitution of the Federal Republic of Nigeria, 1999.

Musgrave (1959) and Oates (1972) opined that the finances and functions of government should be shared in a manner that is acceptable to all involved. Fiscal federalism is the allocation of tax powers and expenditure responsibilities to various levels of government. In Nigeria, this includes the central government, state governments and local government authorities. Finally, Okurounmu (1996) defines fiscal federalism as "intergovernmental fiscal relations as enshrined in a federal constitution providing for the functional responsibilities to be performed by the multi-levels of government and the financial resources that can be raised and shared for the provision of collected goods and services." For the avoidance of doubt therefore, fiscal federalism refers to the allocation of tax-raising powers and expenditure responsibilities between the levels of governments. Accordingly, fiscal federalism is anchored on the following objectives:

1) To ensure correspondence between sub-national expenditure and responsibilities and their financial resources (including transfers from central government) so that functions assigned to sub-national governments can be effectively carried out;

2) To increase that autonomy of sub-national governments by incorporating incentives for them to mobilise revenues of their own;

3) To ensure that the macroeconomic management policies of the central government are not undermined or compromised;

4) To give expenditure discretion to sub-national governments in appropriate areas in order to increase the efficiency of public spending and improve the accountability of sub-national officials to their constituents in the provision of sub-national services; 
5) To incorporate intergovernmental transfers that are administratively simple, transparent and based on objective, stable, non-negotiated criteria;

6) To minimise administrative cost and thereby economise on scarce criteria;

7) To provide 'equalisation' payment to offset the differences in fiscal capacity among states and among local governments so as to ensure that poorer sub-national governments can offer a sufficient amount of key public services;

8) To incorporate mechanisms to support public infrastructure development and its appropriate financing;

9) To support the emergence of a governmental role that is consistent with market-oriented reform;

10) To be consistent with nationally agreed income distribution goals.

\section{THE NeEd FOR Fiscal FEDERALISM IN Nigeria}

Despite the efflorescence of academic work on fiscal federalism in Nigeria, there exists a paucity of writings on the transfer of resources from the federal government to component units to alleviate their ecological, socio-economic and political problems. It is argued that in a federal system where federally collected revenue up to the tune of $90 \%$ is derived from a particular region/state and the method of sharing revenue between the central government and the component units does not adequately compensate the region/state where the bulk of the resources is derived, such contraption is bound to generate feelings of marginalisation, domination and a desire to opt out of the federation. In essence, this study is not concerned with the problems associated with the traditional fiscal transfers between the central government and component units; rather it is concerned with the mode of transfer of resources from the federal government to the component units within the context of the theory and practice of fiscal federalism in Nigeria. The need for fiscal federalism in Nigeria can be itemised as follows:

1) Fiscal federalism gives room for centralisation and decentralisation of collective choices in a country.

2) It also gives room for regional variation in the provision of public goods and services.

3) It ensures optimal production of goods and services which are national in their benefits.

4) Fiscal federalism ensures efficient administration of a large country in terms of size and population.

5) It guarantees efficient redistribution of income in order to achieve balanced growth and development among states and local governments.

6) Fiscal federalism promotes economic growth through policy measures that assist backward states and all hindrances to development.

7) The provision of goods and services that benefit the whole country at large ensures economic use of resources and guarantees economies of large-scale production.

8) The need for fiscal federalism in Nigeria arises from the need to reduce excess load being carried by the federal government in the area of provision of social goods.

9) To ensure correspondence between sub-national expenditure responsibilities and their financial resources so that functions assigned to sub-national governments can be carried out effectively and efficiently.

10) To increase the autonomy of sub-national governments by incorporating incentives for them to mobilise revenues of their own. Specifically, Nigerian fiscal federalism structure involves the allocation of expenditure and tax-raising powers among the three tiers of government.

According to Guyer (1997: 6), "fiscal federalism is deeply rooted in a political arrangement called federalism". 
Fiscal Federalism and Good Governance in Nigeria Since Independence

As a financial relationship between and among existing tiers of government, fiscal federalism deals with the system of transfer of grants through which the federal government shares its revenue with state and local governments.

\section{FisCAL FEDERALISM IN NigERIA}

In view of the underlying imperatives of fiscal federalism, Okoli (2004) maintained that the principles of fiscal autonomy and fiscal integrity are condiciones sine quibus non for the survival and continued existence of a federal system of government. She advocated that each level of government must necessarily have a minimum source of independent revenue and full control of such revenues in order to enable it discharge its constitutional responsibilities. The political economy of fiscal federalism confronts the power relations that underlie the authoritative allocation of resources among the various tiers of the Nigerian federalism underscored by the competing shades of interests among ethnic elites. By the same logic, it deals with the outcome of the same allocative process and the conditions under which it breeds crises rather than to be limited by the straitjacket of specialised approaches which provide a narrow view based on how "the principles of horizontal equity and efficient allocation of resources are fulfilled in the context of fiscal federalism".

A holistic approach goes beyond the treatment of revenue allocation as the distribution of resources to defined tiers, responsibilites and functions, and addresses the power relations in which the struggle between the faction and the ruling class are rooted: territorially, locally, ethnically or numerically. Revenue allocation has a very great potential for conflict, especially between rich and poor regions or states in Nigeria. In fact it was ethnic conflict which largely explained the origin of centralisation of fiscal powers in Nigeria today. With central control over a wide range of policies, the federal government has been able to effect a redistribution of income from the richer to the poorer states. The highly unitary tendencies are however being questioned since Nigeria has adopted a federal rather than a unitary system of government (Idehen, 2009).

As a matter of fact, the greater the fiscal independence through internally generated revenue amongst the component units, the stronger the foundation of its federal system, and the greater the chances of the survival and continued existence of the federation. It is therefore essential that each unit of government in the federation must not only have identifiable independent sources of revenue, but that such independent sources should, to a large extent, provide a solid base for its revenue needs and economic potentialities. A number of constraints and challenges both within and outside the fiscal system are part of the problems that must be solved in order to achieve an effective fiscal system. The challenges to effective fiscal federalism can be identified to include the problem of external debt overcharge, macro-economic instability, distresses in domestic financial system, lack of political stability and above all, bad leadership or leadership ineffectiveness. It has been observed also that good governance cannot be achieved in an environment of political and social instability. Political stability implies an orderly system for a change of government. The absence of an orderly system and dedicated leadership is a great challenge to the operation of an effective fiscal system needed to support economic growth. The challenge is formidable because it is the leadership that would dictate the pattern and direction of fiscal engineering. In view of the foregoing, Ajibola (2008) identified the following as the major challenges of fiscal federalism in Nigeria:

1) The major problem of fiscal federalism in Nigeria could be seen in the mismatch between revenue sources and functions of the various tiers of government. The revenue allocated to the lower tiers of government is lower in comparison to the enormous duties expected of them. This has actually influenced meaningful infrastructural development in the country.

2) Frequent change in government and incessant military coups reduce the operations and effectiveness of fiscal federalism. This is because during military intervention, the constitution is usually suspended in favour of decrees and edicts. In this situation, the principle of fiscal federalism was affected and this in turn affected development in the country, especially within the state and local government areas. 
Fiscal Federalism and Good Governance in Nigeria Since Independence

3) Dwindling revenue due to reduction in the country's export and fluctuations in the price of the nation's commodities in the international commodity market are among the challenges of fiscal federalism in Nigeria.

4) Economic and financial mismanagement which is reflected in corruption and financial impropriety of government functionaries have actually affected development and good governance in Nigeria especially where leaders in the country are corrupt and self-centered.

5) The sharing of federally-generated revenue reflects political application rather than economic consideration.

6) Rapid increase in fiscal unit thereby reducing the funds allocated to each state and local government in the country.

\section{Fiscal Federalism and Political Accomimodation in Nigeria}

Politics since the days of man on earth has been a struggle over scarce resources among competing individuals and groups in society. Allocation of values therefore is the essence of politics and with the existence of accommodative principles attempts can be directly made to fairly distribute available resources to the government. Without the principles of accommodation, the struggle among contending forces in a political community can be Hobbesian, particularly in a plural society like Nigeria where before now government is expected to do everything. Politics of accommodation provides the machinery and mechanism for redressing this challenge. The problem of accommodation exists in every federal state, and is often embedded in the concept of federalism itself. In this regard, Elazar $(1964 ; 1968)$ states that the "great strength of federalism lies in its flexibility but that very strength makes federalism difficult to discuss satisfactorily on a theoretical level."

Federalism has always been conceived as a formula for managing territorially delineated diversity by recognising, rather than denying difference as a basis for structuring government; it provides an appropriate framework for political accommodation. But its effectiveness or success cannot be guaranteed. Even those that are regarded as successful have faced such perennial stress, tension and conflict that statehood and national cohesion have been fragile at best. Sources of tension, especially among developing federations include abject poverty, economic underdevelopment, bad governance, poor service delivery, contested citizenship and state fragility which make political accommodation a salient subject. As it were, federalism is not only about high stake elite politics and privileges or creation of cultures of entitlements, it is also about efficient service delivery, poverty alleviation and overall development which in the final analysis would be crucial for measuring its success or failure. The formula for achieving this end is political accommodation.

According to Jega (2007: 205), fiscal federalism deals with the issues of relationship between revenue generation and sharing in a federal system of government which has always been debatable and contentious. It is also defined as a system of revenue generation, allocation and redistribution within a federal system. It is that aspect of federalism which concerns the financial and attendant functions and responsibilities of component units within a federal structure. Ekpo (2004) identifies some principles which guide the conduct of fiscal federalism in Nigeria. The major principles include the principle of accommodation, principle of correction of spill-over effects, and principle of social safety net and principle of derivation. The principle of accommodation relates to the ability or requirement of a federal fiscal system to accommodate diversity (i.e. varieties and differences) in its supply of national, regional and local public goods. Second is the principle that speaks to the correction of spill-over effects which means that a fiscal federalism instrument must be able to address "externalities" (i.e. negative and positive effects of distribution on different geo-political zones). Simply put, for instance, if fiscal distribution of public goods leads to the development of State A, mechanisms must be put in place to ensure that State B does not benefit from such interventions, and is supported in a manner that the negative effect of State A's positive development does not continue to engender a negative development in State B. Third is the 
principle of, as Ekpo puts it, "minimum provision of essential public goods and services" which is summarised into the social safety net principle of federalism. Simply put, no citizen should be allowed to degenerate to a certain level of impoverishment occasioned by resource distribution. This means that regardless of diversity and inequality in resource endowment among component units, conscious effort must be made to prevent citizens from sinking below certain levels. Fourth is the principle of derivation which dictates that the component units of a federal system must be able to get a "reasonable benefit" from revenue or resources generated from their enclave.

According to Eghosa Osaghae (2006), all identities have political significance and those identities that are territorially delineated and have been made a basis for political action are relevant in the discourse of accommodation. He stressed further that the mere fact that a country is diverse does not necessarily make it divided, troublesome or difficult to manage. A lot depends on the configurations of power, number, and extent of quality and inequality among consistent groups and why and how differences are mobilised and politicised to articulate grievances, seek redress and make contesting nationalist claims and demands including recognition and protection of identity, self-determination and political autonomy, on the state and other groups within it. If the claims are irreconcilable and made through war and violence, political accommodation may be difficult if not impossible. In other words, political accommodation is only meaningful when the competing claims are reconcilable and the various groups have agreed to stay together.

Political accommodation has other significant components that need to be critically examined. One is the materialist basis of accommodation which is often underplayed by analysts. People's desire for material wellbeing is a big problem, which more often than not, makes inhabitants of a given territory to seek political accommodation. This is the case in federal systems where those that join the union desire to reap the material benefits from pooling resources. Ideally, political accommodation is part and parcel of the federalist thought that enhances poor(er) units of federal union to share from and have access to the resources of the rich(er) units. Political accommodation refers to the principle of tolerance and forebearance that makes for fairness, equity and justice in the relationship among the various groups within a political entity. In effect, it is about 'unity without uniformity' in a federal system. It is the basis upon which heterogeneous entities can manage the diversities in natural endowment and economic viability, linguistic, cultural and ethnic diversity. The deceptive belief that rich units should get richer and poor units poorer negates the federal principle of political accommodation; rather fiscal federalism should bring about good governance, balanced and even development (Osaghae, 2010). In fact, Nigerian federalism is beclouded by the challenge of how the various components of the union can accommodate each other in terms of resource distribution as well as power sharing among them. In short, scholars (Suberu, 2012; Benjamin, 2012; Osaghae, 2006, 2010) of federalism are concerned about how federalism can bring about the equitable accommodation of the competing claims to self determination, power, and resources to the satisfaction of several hundred ethnic nationalities, politico-administrative regions, and the major religious groups (Christian and Muslim) despite inequalities in population, size, resource endowment and level of development.

\section{FisCAL FEDERALISM IN NigERIA (1946-2014)}

In the context of Nigeria and given the basis for co-existence and unity, fiscal federalism has long been an important and central feature of intergovernmental relations. Even though the construction of a stable and acceptable intergovernmental fiscal arrangement has been the subject of various commissions, committees and other efforts since the amalgamation of southern and northern Nigeria in 1914, the issue remains on the front burner today, still evoking a great deal of passion and virulent contestation. The recent stalemate over this matter in the Political Reform Conference and the subsequent walk-out by the South-South delegates attests to this.

The first phase of the development of fiscal federalism in Nigeria occurred during the period 1948 to 1952. This phase was marked by a centralised financial arrangement in which the excess in the budget of the central government was allocated to regional governments on the principle of derivation. The expenditure needs of 
Fiscal Federalism and Good Governance in Nigeria Since Independence

the central government thus took precedence. In the second phase (1952-1954), autonomous revenue and tax jurisdiction for the regional governments were introduced in addition to the operation of the principle of derivation for the sharing of federally collected revenue. The basic elements of the second phase were carried over to the third phase (1954-1959). A major distinguishing factor of this phase was the emphasis on the derivation principle in the sharing of federally collected revenue. This pleased the Northern and Western Region given the boom in their export commodities: Cotton and Groundnut in the North, and Cocoa in the West. The Eastern Region whose main export crop (palm oil) was facing difficult times in the global market was unhappy with its application (Egwaikhide and Isumonah, 2001). In general, this was the period of statecentered fiscal federalism. It has remained the reference point by present-day proponents of either higher emphasis on derivation or resource control, especially minorities of the oil-producing areas. Some advocates of resource control actually equate it with a $100 \%$ derivation.

The fourth phase (1960-1964) which remains the main pillar of fiscal federalism to date was the product of postindependence politics. This phase sought to reduce the earlier emphasis on regional financial independence based on the principle of derivation. It was argued that the financial stability of the federal government was expedient for the stability of the regions. Following from this, the 1960/1963 constitutions provided for 50\% derivation in respect of revenue from all minerals. It was in this phase that the distributable pool account (the forerunner of today's Federation Account) was instituted. Specified tax proceeds collected by the federal government were paid into this account and then distributed to the regions based on the following criteria:

1) Continuity in government services;

2) Minimum responsibilities of each government;

3) Need based on the population size of the region;

4) Balanced development of the federation.

The fifth phase, beginning from 1966 has been characterised by increasing centralisation as the states have become increasingly more dependent on the centre. This period coincided largely with the military's stranglehold on Nigeria. The centrist command structure of the military was brought to bear on intergovernmental fiscal relationships. A number of historical occurrences and events were exploited to promote the centrist preference of military rulers. Of these, the civil war and state creation were the most important. The rally around the need for national unity as a result of the civil war was exploited to strengthen the centre at the expense of the states. The creation of states from the regions and continuous fragmentation of the states became instruments for promoting a concentration of fiscal authority at the centre. In addition to these, various decrees were promulgated expropriating tax authorities and jurisdiction from the states. The concept of a predatory centre is apt in describing this period. The centrist philosophy has found its way into the 1999 constitution handed down by the military.

Fiscal centralisation has been too attractive for democratically elected governments at the centre. Thus, calls by lower tiers of government for a more decentralised fiscal arrangement have continued to fall on deaf ears. Fiscal mobilisation commissions appointed by the central government and the National Assembly have continued to formulate revenue allocation formulas which maintain fiscal centralism. In Nigeria, various efforts have been adopted to reduce/eliminate intergovernmental fiscal imbalances and ensure that each tier of government has adequate resources for the effective discharge of its statutory functions. Some of the mechanisms put in place to effect the transfer of resources from the federal government to the lower tiers of government are sharing of tax revenue, grants-in-aids, and loans (Fajana, 2001: 111). The revenue sharing among the tiers of government constitutes the most important instrument of intergovernmental financial transfer of funds. In order to ensure that the revenue sharing is done on a rational basis, the exercise has usually been guided by the recommendation of the commissions and committees on Revenue Allocation. 
Fiscal Federalism and Good Governance in Nigeria Since Independence

Before 1988, these commissions were ad-hoc in nature, their establishment being closely linked to major political and constitutional changes. In 1988, the Revenue Allocation, Mobilisation and Fiscal Commission (RMAFC) was established as a permanent body with the primary responsibility of constant reviews of the bases of revenue sharing among the three levels of government and among the states of the federation. The major revenue review commissions and committees whose recommendations have determined the allocation of revenue between the units of government in post-independence Nigeria from 1960-2014 include:

1) Raisman-Trees Commission (1958);

2) Binns Commission (1964);

3) Dina Interim Revenue Committee (1968);

4) Aboyade Technical Commission (1977);

5) Okigbo Commission (1980);

6) National Revenue Mobilisation, Allocation and Fiscal Commission $(1988,1999,2014)$ etc.

Table I

Revenue Allocation in Nigeria (1946-2014)

\begin{tabular}{|c|c|c|c|}
\hline $\mathbf{S} / \mathbf{N}$ & COMMISSIONS & RECOMMENDATION & BASIC FEATURES \\
\hline 1 & Philipson (1946) & Derivation & Balance after meeting the budget of Central Government. \\
\hline 2 & Hick (1951) & Derivation & Nil \\
\hline 3 & Chicks (1953) & Derivation & Nil \\
\hline 4 & Raisman (1958) & Fiscal autonomy & North- $40 \%$, West- 31, East- $24 \%$, South- $5 \%$ \\
\hline 5 & Binns (1964) & Fiscal autonomy & North- $40 \%$, West- $20 \%$, East- 30\%,Mid-west- $8 \%$ \\
\hline 6 & Decree 15, 1967 & Fiscal autonomy & Nil \\
\hline 7 & Dina 1968 & Even Development & Nil \\
\hline 8 & Decree 13, 1970 & Population (50\%) & Nil \\
\hline 9 & Decree 9, 1971 & Same as above & Transferred rents to Federal government \\
\hline 10 & Decree 6, 1975 & Same as above & Nil \\
\hline 11 & Aboyade, 1977 & Fiscal efficiency & Fed. Government- $75 \%$, State- $30 \%$, Local- 10 \\
\hline 12 & Okigbo, 1980 & Population $(40 \%)$ & Fed. Government- 53, State- 30, Local- 10 \\
\hline 13 & Act of 1981 & Same as above & Federal- 55, State- 30.5, Local- 10, Ecology- 1 \\
\hline 14 & Decree 36,1984 & Same as above & Federal- $55 \%$, State- $32.5 \%$, Local- $10 \%$ \\
\hline 15 & Danjuma, 1989 & Equality $(40 \%)$ & Federal- $47 \%$, State- $30 \%$, Local- $15 \%$, F.C.T.- 10 \\
\hline 16 & AFRC App, 1990 & Same as above & Federal- 50\%, State- $30 \%$, Local- 15\%, Eco- $1 \%$ \\
\hline 17 & AFRC App, 1992 & Same as 16 above & Federal- 50\%, State- $25 \%$, Local- $20 \%$ \\
\hline 18 & AFRC App, 1992 & Same as 17 above & Federal- $48.5 \%$, State- $24 \%$, Local- $20 \%$ \\
\hline 19 & RMAFC, 2001 & Not Available & Federal- $41.5 \%$, State- $31.0 \%$, Local- $61.0 \%$ \\
\hline 20 & Executive 2002 & Not Available & Federal- 56\%, State- $24 \%$, Local- $20 \%$ \\
\hline 21 & Executive 2002 & Not Available & Federal- $54.68 \%$, State- $24.72 \%$, Local- $20.60 \%$ \\
\hline 22 & RMAFC 2004 & Not Available & Federal- $49.17 \%$, State- $31.10 \%$, Local- $15.2 \%$ \\
\hline 23 & RMAFC 2009 & Not Available & Federal- $52.68 \%$, State- 26.72 , Local- $20.00 \%$ \\
\hline 24 & Confab 2014 & Not Available & Federal- $42.25 \%$, State- $35.0 \%$, Local- $22.5 \%$ \\
\hline
\end{tabular}

Source: Adapted from Abubakar (2004). 
The inception of revenue allocation in Nigeria has been put at 1946 when the Richards constitution came into effect. Although the constitution was not strictly federal, the creation of the regional level of government immediately raised the question of allocating revenue among the central government, the new regional centres and the old Native Administration. This gave the process a political character quite early and tied it to the class formation project of the nationalist elite which then joined in the competition to inherit political power from Colonial Britain. In this way, revenue allocation became central to Nigerian federalism and the struggle for power and resources. The Philipson constitution's recommendation (1946) of derivation as the allocation principle through which a region would benefit from its non-declared revenue according to the proportion of its contribution to the central revenue, set the pace for the struggle that was to follow. The principle of derivation was unacceptable because it was believed that it unduly favoured some regions at the expense of the others. Thus by 1948, the elite from the Northern region had began to question the derivation principle and made revenue allocation a major issue at the general conference on the review of the Richard's constitution in 1950. In addition to pressures relating to the accuracy of the data on which derivation was calculated, the principle was jettisoned as the sole basis of allocation and replaced with needs (population) and national interest by the Hicks-Philipson commission. Yet the struggle to correct fiscal imbalances between the regions was far from over, as the regional elite struggled to corner large chunks of resources. By the time the federal constitution of 1954 came into existence, the derivation principle had come back into reckoning as recommended by the Chick Commission of 1953. Yet in 1957 the principle of derivation which indeed had favoured the elite of the western region became once more the chief allocative principle. That same year, the Raisman and Trees commission sought to remove the fiscal imbalance between the western and other regions by narrowing the application of derivation, and setting up the Distributable Pool Account (DPA) for other taxes which were not declared regional or federal. This was made up of $30 \%$ mining royalties and rent and $30 \%$ of general import revenue to be allocated to the regional government in the following proportions: North- $40 \%$, West- $24 \%$, East- $31 \%$ and Southern Cameroun 5\%. The Raisman and Trees recommendation formed the core of Nigeria's revenue allocation system up till the late 1960s. Its significance lay in its creation of the DPA as a counter-balance to derivation, thus defining to a large extent, the poles of conflict around which the struggle over revenue were to take place after independence.

Although the Dina Commission of 1968 attempted to review the Raisman and Trees report and did recommend Federal control of the larger part of revenues within the context of a new twelve-state structure, its proposals failed to see the light of the day thus creating a vacuum in which the federal military government effectively centralised the allocative process. Through Decrees 15 of 1967, 13 of 1970, 9 of 1971 and 6 of 1975, the balance of control and access to revenue tilted towards fiscal centralisation at the federal level. This process of transformation was effected through the progressive reduction of the principle of derivation and the strengthening of the principle of DPA. The federal government as the very vortex of power became the ultimate price in politics, and all attention shifted to the context for access to power and the capacity to authoritatively allocate resources at the centre. Worse still, the nature of oil wealth spawned a political culture in which emphasis was on how to share the providential wealth, rather than how to engage in the production of renewable and viable alternatives. Under oil, fiscal federalism in Nigeria and the revenue allocation system has gone through several convulsions which culminated in the tightening of the grip of federal power over the entire process. What the preceding shows is that the politicisation of revenue sharing and its immersion in the contests over access to state and power are at the root of the unresolved question of intergovernmental fiscal relations in Nigeria (Idehen, 2009).

\section{THE Concept of Good Governance}

The fundamental function of every elected representative is to ensure the delivery of expected dividends through the various machineries of governance established or else the electorate's basic needs in any political system may be elusive. However, it has been observed that Nigerian democracy is fraught with excruciating difficulties possibly due to the fact that people have spent most part of fifty years of independence under military dictatorship 
Fiscal Federalism and Good Governance in Nigeria Since Independence

during which the nation's resources were squandered, our growth stunted, and many of our aspirations as a people frustrated. Perhaps, a good starting point is to look at the concept of governance. Governance relates to decisions that define expectations, grant powers, or verify the performance of government. It consists of either a separate process or of a specific part of management or leadership process. Sometimes people set up government to administer these processes and systems (Wikipedia, the free Encyclopedia, 2011). Governance has also been referred to as "the exercise of political power to manage a nation's affairs... it encompasses the state's institutional and structural arrangements, decision making processes and implementation capacity and the relationship between governance so broadly defined clearly" (Landel- Mills and Serageld, 1991: 56).

Governance therefore involves choice regarding rules, policies, institutions and the resultant structures that collectively provide socio-economic incentives and constraints for different activities. Governance becomes vibrant when preceding policy choices can be modified to aid current development in a precarious and dynamic environment in order to ensure the relevance and effectiveness of policies and institutions so as to achieve the revered desire of a society. Hence, it is more than making a change in a once-and-for-all manner or convalescing from a setback; rather it is a continuous process to ensure continued existence and prosperity. In the context of the foregoing, good governance can be viewed as: a logical flow in the ability of state leadership to manage efficiently and effectively the resources and institutions of the state in such a manner that anarchy and chaos are absent in the political system; unwavering penchant for rule of law and constitutionalism; and pursuance of policies and programmes that would guarantee political and economic stability such that the needs and desires of the citizenry are actualised (Iyoha et al, 2007: 612). In essence, governance becomes "good" when it is operated in accordance with legal and ethical principles as conceived by society (Mohidden, 1997). Good governance thus relates to the soundness of the guiding structure, mechanism, and process which direct socio-economic and political relationship of a nation. It comprises of three interrelated sphere of government: administrative, political and economic. It includes quality service and fair, transparent, accountable, participatory and corrupt free society. Thus, the important components of good governance require brief mentioning. First is adherence to the rule of law. This means that everything needs to be done in accordance with the law. There must be equality before the law irrespective of the class of people. The law should be fair and the implementation of same should be humane. Acts of the ruler and the ruled should be subject to the dictates of the law before ordinary courts of the land.

Effective participation is another cardinal principle of good governance. This shows that participation irrespective of gender, whether male or female is a major foundation of good governance. Similarly, there is the need for transparency, responsiveness, and consensus. This means that decisions and its implementation should follow laid down rules and regulations. States should not be governed as secret societies and everybody especially those affected by government decisions should have required information on the affairs of the state. Good governance requires that institutions and processes should try to serve all stakeholders within a reasonable timeframe. Also government should carry out enough consultation before taking decisions in certain national interest. To achieve this, government needs to understand the culture, history, and values of a given society. In the event of conflict, steps should be taken to mediate between the people according to law and justice. In the same vein, equity and inclusiveness, effectiveness and efficiency, and accountability are significant aspects of good governance. The society should be built on fairness and egalitarianism. An inclusive government as opposed to winner-takes-all needs to be promoted. Finally, government should be accountable to the people. It should be run in such a manner that people can hold the government accountable. Accountability should be visible in all sectors of the society.

\section{FisCAL FEDERALISM AND Good GovernANCE IN NigERIA SinCE INDEPENDENCE}

For five decades now, the Nigerian federation has witnessed tremendous transformation in its structure. From a federation of three large semi-autonomous and powerful regions at independence in 1960, the country has evolved into a federal structure of thirty-six states and a federal capital territory. The number of local government 
areas including area councils has also been characterised by remarkable growth, standing currently as contained in the 1999 constitution at 774. This has resulted in structural changes and progressively strengthening the powers of the federal governments and weakening the powers of the state and local government. This as Fajana (2001: 104) observes, has made for some changes in the intergovernmental division of powers and responsibilities between the federal government and other tiers of government. Some of the functions that were under the control of the state and local governments have been transformed to the concurrent legislative list to allow for participation. Examples are agriculture, primary education, primary healthcare, and rural electrification. A major issue of interest in the history of revenue sharing is the fact that in earlier years, every constitutional change in the country was invariably accompanied by the establishment of a commission/ committee to look at the revenue sharing situation vis-á-vis the constitution.

On the other content of the revenue formula, the criteria of derivation were dominant and before the Aboyade committee of 1977, emphasis was largely on horizontal sharing. Vertical sharing between component units of the federation did not appear to have posed much controversy. From the Aboyade recommendations however, vertical allocations began to gain prominence and attention but never appeared to be major issues of contention until 1999 (Abubakar, 2004: 6-7). The criteria recommended by the earlier commissions were continuity of existing levels of services: basic responsibility of each regional government, population, balanced development and derivation. In 1964, the Binn Commission recommended that the distributable pool account should be increased from 30 to $35 \%$ of revenue from import duties, mining rents and royalties. It also recommended the principle of financial comparability in addition to the existing criteria. By May $29^{\text {th }} 2007$ when President Obasanjo left office, the process of fiscal federalism had become corroded by mutual suspicion and lack of confidence in the existing institutions and processes of fiscal federalism. In 2007, the Revenue Mobilisation, Allocation and Fiscal Commission took the Obasanjo-led federal government to court for illegally withdrawing 2.071 Trillion Naira from the federal account. In addition, the Excess Crude Account has been an issue of conflict between the federal and state governments as it relates to its basis and usage. However in 2010, efforts were being made to replace the account with the National Sovereign Wealth Fund (NSWF). The Bill in this respect was submitted to the National Assembly by President Goodluck Jonathan, which functions have been aimed at ensuring minimum national development.

Nigeria became a federation before independence in 1960. It was properly handled by such frontline nationalists as Dr. Nnamdi Azikiwe, Chief Obafemi Awolowo, Alhaji Tafawa Balewa and others; they quite accepted federalism that was regionalistic in nature. The three regions were the Northern region comprising the Hausa, Fulani, Kanuri and others; the Western region comprising the Yoruba, Edo and other tribes; and finally the Eastern region which was made up of the Igbo, Efik, Izon and other tribes. Each region was governed independently without any undue interference from the central government. This propelled our economic development as each region mobilised its human and material resources in revenue generation and control. Their frontline politicians and technocrats identified their particular national endowment and harnessed it, and ploughed back the proceeds towards the development of the region.

The Eastern region was producing palm oil in large quantity, the Western region cocoa, the Northern region pyramids of cereals and groundnuts, and this enabled the people under the founding fathers to experience massive infrastructure facelift. The roads were good, the distribution of social amenities were without prejudice. There was a sense of duty and belonging in every citizen, especially as unemployment was not visible then. At that time, our currency was with much value than what is the case today; the citizens of Nigeria had some dignity and respect internationally, unlike today that everybody is a suspect. There is no gainsaying that what we practice today is a mockery of true federalism, and so good governance is still very remote and inaccessible. How can we have good governance in a system where the politics of the nation is not determinable? Where democracy is very nascent and we are proud of that? For a democracy that has lasted for over forty years, we make bold to say that ours is a nascent democracy? What is the possibility of good governance in a nation where 
Fiscal Federalism and Good Governance in Nigeria Since Independence

selection takes the place of election, where we profess democracy as government of the people, but practice oligarchy, government of a few, leaving a greater majority of the people to struggle below the poverty line? In a true federalism, the electoral process must be free and fair, no god-fatherism, political appointments must purely be on merit, civil service recruitment must also be on merit. There must be judicial autonomy; freedom of the press; clearly spelt out separation of powers among the Executive, Legislature and Judiciary; the different tiers of government must have their fair share in revenue generation and resource control. In a true federalism, the need for total education cannot be over-emphasised; creation of jobs should substitute job seeking.

The character of fiscal federalism in Nigeria since independence has created an imbalance in the fiscal powers of the federal and the lower tiers of government. The expansion in the political structure has created a high degree of concentration of powers in the federal government to the detriment of the other tiers of government. This makes the federal government to change at will, its fiscal powers and responsibilities vis-á-vis the lower levels of government. The state and local governments have limited sources of internally generated revenue at their disposal; this makes them financially weak and excessively dependent on the federal account allocations for funds to discharge their functions. In most cases, the states rely heavily on the federation account allocations for the discharge of most of their responsibilities. In addition, such allocations are not even adequate for the performance of most of the functions of the lower levels of government. The result of this is an increasing fiscal gap and lapses in the discharge of the responsibilities of lower tiers of government (Fajana, 2001: 120).

The lack of equilibrium in the availability of financial resources as between the federal and lower tiers of government in the Nigerian federation has severe implications for economic and political development of the country. As observed by Fajana (2001: 120), the heavy concentration of fiscal powers and financial resources in the federal government has been partly responsible for the unhealthy inter-ethnic and regional competition for the control of the government. It is in this context that the demand for resource control emanated, broadly and vaguely defined as the control/ownership of revenues from petroleum resources where they are produced (Jega, 2007: 206). In addition, the fiscal federalism structure in Nigeria since independence has made for "undue politicisation of the intergovernmental revenue allocation", which had tended to undermine both its efficiency and equity. The unequal application of the grants-in-aids by the federal government to the lower units of government, most especially under civilian regime has created feelings of marginalisation among the component units and makes nonsense of the relevance of the mechanism as a tool of fiscal adjustment.

The fiscal federalism system in terms of the vertical allocation of revenue between the federal and lower tiers of government has led to the mistrust of the federal government by the state and local governments. The state governments have always called for a fairer share in the allocation to enable them cope with massive responsibilities at the state level. A contentious issue in Nigerian intergovernmental fiscal relations between 1960 and 2014 has been that of an acceptable horizontal revenue sharing criterion. The complexity of this problem is reflected in the large number of principles and criteria that have been adopted and applied over the years in Nigeria. These issues and situation in Nigeria's fiscal federalism from 1960 till date has accounted for the constant conflict among the tiers of government in the Nigerian federal structure and the crises of governance. Even though revenue allocation is a contentious issue in most federal setups, there is the need to evolve a stable and acceptable revenue sharing arrangement in Nigeria that will minimise intergovernmental tensions and promote national unity and good governance with the sole aim of enhancing national growth and development. The nature and pattern of fiscal federalism has continued to affect the pattern of intergovernmental relations in the Nigerian federation and in addition, affected good governance.

Finally, in general, fiscal federalism in Nigeria since independence has not been adequately addressed. The governors have demanded an impartial sharing organ as well as details of the federation account. The lack of transparency and accountability in the fiscal process have compounded existing crises of confidence in the process and have hindered the achievement of good governance in the Nigerian federation. 


\section{CONCLUSION AND RECOMIMENDATIONS}

Nigeria has since 1946 accepted the principle of federalism and its derived concept of fiscal federalism. The Nigerian state since independence has been battling with how best to structure its revenue sharing arrangement in order to ensure peaceful and cordial relations among the units of government. In order to draw the curtain, this paper advances the following recommendations:

1) There should be a re-examination of the situation with the main concern of balancing the federal structure to ensure more resources at the lower levels for effective grass root and overall national development. This can be achieved through the devolution of more powers and responsibilities to the lower levels, which will lead to the diversification and strengthening of their revenue base.

2) The restructuring of the vertical allocation of revenue will provide a conducive environment for peaceful coexistence, good governance and balanced development of the Nigerian state. In this regard, the value added tax being managed by the federal government should be disbursed mainly to the states and local governments.

3) Fiscal federalism in Nigeria has been characterised by increasing lack of congruence between the revenue capacities and expenditure responsibilities among the different tiers of government, and this could be addressed not by the interventionist approach like grants-in-aids, but by empowering the levels of governments to improve their revenue base through a more rational and equitable allocation of fiscal powers. This will help in ensuring intergovernmental fiscal harmony for national growth and development.

4) There should be total reformation of revenue generation, expenditure prioritisation and better relations among the tiers of government.

5) For good governance to be achieved in Nigeria, there is the need to adopt the horizontal form of revenue allocation which can bring about active competition and even development among the states and will further enhance good fiscal relations in Nigeria.

6) Furthermore, Nigeria has to go back to the basics and adopt and institutionalise tested fiscal principles and arrangements which have worked well in other federal systems and which could enable it cope and resolve the challenges of fiscal federalism in the future.

7) Given the need to reduce the intense competition for the control of the centre, and the fact that governance at both the state and local government levels is nearer, and therefore more directly beneficial to the people than that of the federal level, the state and local governments combined should get at least $65 \%$ of the share of the vertical revenue allocation. A distribution in the proportion of $40 \%$ to the states, $25 \%$ to local governments and $35 \%$ to the federal government, would be more in tune with the imperatives of ensuring that governance satisfies the most fundamental needs of the people at levels of governance that matter most to them and affect them directly. It is expected this will make for intergovernmental fiscal harmony and ensure an efficient allocation of resources for the development of the Nigerian state.

8) There is the need to ensure that the distribution of revenue encourages each state and local government to improve internal revenue generation, and not to constantly and wholly depend on funds from the federation account. This will enhance good governance in Nigeria.

9) For fiscal federalism and good governance to be achieved, there should be a breakout from the centripetal approach of federalism which lays emphasis on centralisation and unity in the organisation of government, to the centrifugal approach which lays emphasis on promoting decentralisation and comprehensive local/unit decision-making autonomy. 
Fiscal Federalism and Good Governance in Nigeria Since Independence

10) The true federalism practiced in the first republic from 1960-1966 which brought about even development in the country, should be revisited.

\section{REFERENCES}

Abubakar, H. "Intergovernmental Fiscal Relations in Nigeria: Nature and Problems". Being a paper presented at the National Conference on Public Administration and Good Governance, organised by the Department of Public Administration, Ahmadu Bello University, Zaria in Conjunction with Office of the Head of Civil Service of the Federation, Abuja, March $9^{\text {th }}-12^{\text {th }}, 2004$.

Akindele, S. T. and Olaopa, O. "Fiscal Federalism and Local Government Finance in Nigeria." Available at:http://unpan1.un.org/intradoc/groups/public/documents/CAFRAD/UNPAN008121.pdf. Accessed: 8 $^{\text {th }}$ November, 2015, 2002.

Ajibola, R. Public Finance: Theory and Practice. Lagos: AVL Publishing, 2008.

Awa, E. Issues in Federalism. Benin-City: Ethiope Publishers, 1976.

Benjamin, S. A. "Politics of Accommodation in Nigeria's Federalism [1993-2007]. [Dissertation] Faculty of Social Sciences, University of Ibadan, 2012.

Deutsche, D. The Consequences of Modernity. Oxford: Blackwell, 1956.

Dicey, A. V. Introduction to the Study of Law of the Constitution. London: Macmillian, 1924.

Elazar, D. Exploring Federalism. Tuscaloosa: Achama University Press, 1987.

Elaigwu, I. The Nigerian Federation: Its Foundations and Future Prospects. Abuja: National Council on Inter- Relations, 1994.

Fajana, 0. "Three and a-half Decades of Fiscal Federalism in Nigeria" in Elaigwu, I. J., Foundations of Nigerian Federalism 1960-1995. Foundations of Nigerian Federalism Series: Volume 3, Jos, Institute of Governance and Social Research, Second Edition, 2001.

Friedrisech, C. Constitutional Government and Politics. New York: Harper, 1937.

Gamble, A., and Payne, A. The New Regionalism. Bassingstoke: Macmilian, 1996.

Hague, R., and Harrop, M. Comparative Government and Politics. Hampshire: Macmilian, 2001.

Idehen, R. "Inequality, Ethno-Regional Conflict and Fiscal Federalism in Nigeria." Igbinedion Journal of Diplomacy and Strategy, Vol. 1 No. 1, 2009.

Iyoha, F. E., and Idada, W. “Good Governance and Poverty in Nigeria” in Akpotor, A. B., Afolabi, A. O., Aighokhaevbolo, M. O., Iganiga, A. O., and Odiagbe, O. S., (eds.) Corruption, Cost of Governance and Sustainable Development in Nigeria. Cost of Governance in Nigeria: An Evaluative Analysis. Ekpoma: Ambrose Alli University Publishing House, 2007.

Jega, A. "Fiscal Federalism: Towards coping and Resolving Future Challenges" in Elaigwu, I. J. (ed), Fiscal Federalism in Nigeria: Facing the Challenges of the Future. Jos: Aha Publishing House, 2007.

Livingston, W. S. "A Note on the Nature of Federalism." Political Science Quarterly. Vol. 67, No. 1, March, 1952.

Mohidden, A. "Stock Taking and Assessment of Democracy and Good Governance" in Proceedings of the Development Policy Management Forum Conference on Democracy, Civil Society and Governance in Africa, Addis Ababa, Ethiopia, 1997.

Mohammed, I. A. "The Federal Principle and Local Government Autonomy in Nigeria", Abuja Journal of Administration, Vol. 1, No 2, August, 2002. 
Fiscal Federalism and Good Governance in Nigeria Since Independence

Nwabueze, B. O. The Presidential Constitution of Nigeria. London: C. Hurst Company in association with Nwamife Publishers, 1982.

Onimode, B. "Fiscal Federalism in Nigeria: Options for the $21^{\text {st }}$ Century". A Research Report. Ibadan: NISER, 2000.

Osaghae, E. E. "Federalism and Political Accommodation: The Nigerian Experience in Comparative Perspective." NISER Distinguished Lecture Series, No.1, 2006, Nigerian Institute of Social and Economic Research, Ibadan, 2006.

Okurounmu, T. O. "Fiscal Federalism: Revenue Allocation for Economic Development in Nigeria." Central Bank of Nigeria Publication Bullion, Vol. 20, No. 2, April-June, 1996.

Onwe, D. "Politics of Revenue Allocation." Abakiliki, Unpublished Lecture Series: Ebonyi State University, 2011.

Okoli, M. U. Inter-Governmental Relations: Theory and Practice. Awka: Fountain Publishers, 2004.

Okoli, D. O., and Eze, F. E. Local Government Administration in Nigeria: Concepts and Applications. Enugu: John Jacob's Classic Publishers Ltd, 2004.

Ozor, E. Public Enterprises in Nigeria: A Study in Public Policy-Making in a Challenging Political Economy. Ibadan: University Press Plc, 2004.

Oyovbaire, S. E. "The Theory of Federalism: A Critical Appraisal." Nigerian Journal of Political Science. Vol. 1, No. 2, 1979.

Suberu, R. T. "Equality and Unity in Diversity for Development." Vol. 4, $5^{\text {th }}$ International Conference on Federalism, Addis Ababa, Ethiopia, 2012.

Tamuno, T. "True Federalism in the $21^{\text {st }}$ Century." Vanguard Newspaper, $4^{\text {th }}$ July, 2005.

Ricardo, D. Modern Comparative Politics: Approaches, Methods and Issues. Delhi: Rajkanai Electric Press, 1993.

Riker, W. Federalism: Origin, Operations and Significance. Boston: Little Brown and Company, 1964.

Vincent, O. "Fiscal Federalism: The Nigerian Experience." Ibadan Proceedings of NES, the $4^{\text {th }}$ Public Lecture Held in Abuja, $11^{\text {th }}$ December, 2001.

Wheare, K. C. Federal Government. London: University Press, 1967.

Citation: Evalsam Samuel Ecoma, M.Sc., Chinyere Samuel Ecoma, Ph.D., "Fiscal Federalism and Good Governance in Nigeria Since Independence". American Research Journal of Humanities and Social Sciences, vol 4, no. 1, 2018, pp. 1-16.

Copyright (c) 2018 Evalsam Samuel Ecoma, M.Sc., Chinyere Samuel Ecoma, Ph.D., This is an open access article distributed under the Creative Commons Attribution License, which permits unrestricted use, distribution, and reproduction in any medium, provided the original work is properly cited. 